NEWS

\title{
Gene-testing firms face legal battle
}

\section{The state of California is clamping down on companies that offer direct-to-consumer genetic testing in a move that threatens the burgeoning industry.} Meredith Wadman looks at a grey area in US regulation.

Last Wednesday, as California governor Arnold Schwarzenegger prepared to tell a biotechnology industry convention in San Diego that his state "is one of the best places to set up shop", Kári Stefansson was opening a letter that had just landed on his desk at deCODE genetics in Reykjavik, Iceland.

The letter read: "It has come to the attention of the California Department of Public Health...that deCODEme Genetics is in violation of California law" for failing to have a clinical laboratory licence in the state and offering genetic tests to consumers resident in the state without a physician's order. It gave deCODE until 23 June to submit a plan showing how it would correct the situation, or face "civil and/ or criminal sanctions".

Stefansson's high-profile company is one of 13 genetic-testing firms that have been targeted during the past two weeks by the California agency with a letter to "cease and desist" selling tests to California's residents. The directive poses a serious challenge to plans for a new era of Internet-based, direct-to-consumer genetic testing. The companies include Californian businesses 23 andMe and Navigenics, which have begun marketing test packages based on genome-wide arrays within the past six months, and DNATraits.com, based in Houston, Texas, which counsels prospective parents on the genetic risks faced by their future offspring.

DNA Direct, a San Francisco-based firm founded in 2003 that offers tests for familiar mutations in well-characterized genes such as $B R C A 1$ and BRCA2, which convey an increased risk of breast cancer, did not receive a letter.

"If these companies were constrained from reaching out to consumers directly, it would certainly cause some near-term difficulty for their business," says life-sciences analyst John Sullivan at Leerink Swann, an investment bank based in Boston.

During a public meeting on 13 June, Karen Nickel, California's chief of laboratory field services, who wrote the letter, said that consumer complaints had triggered an

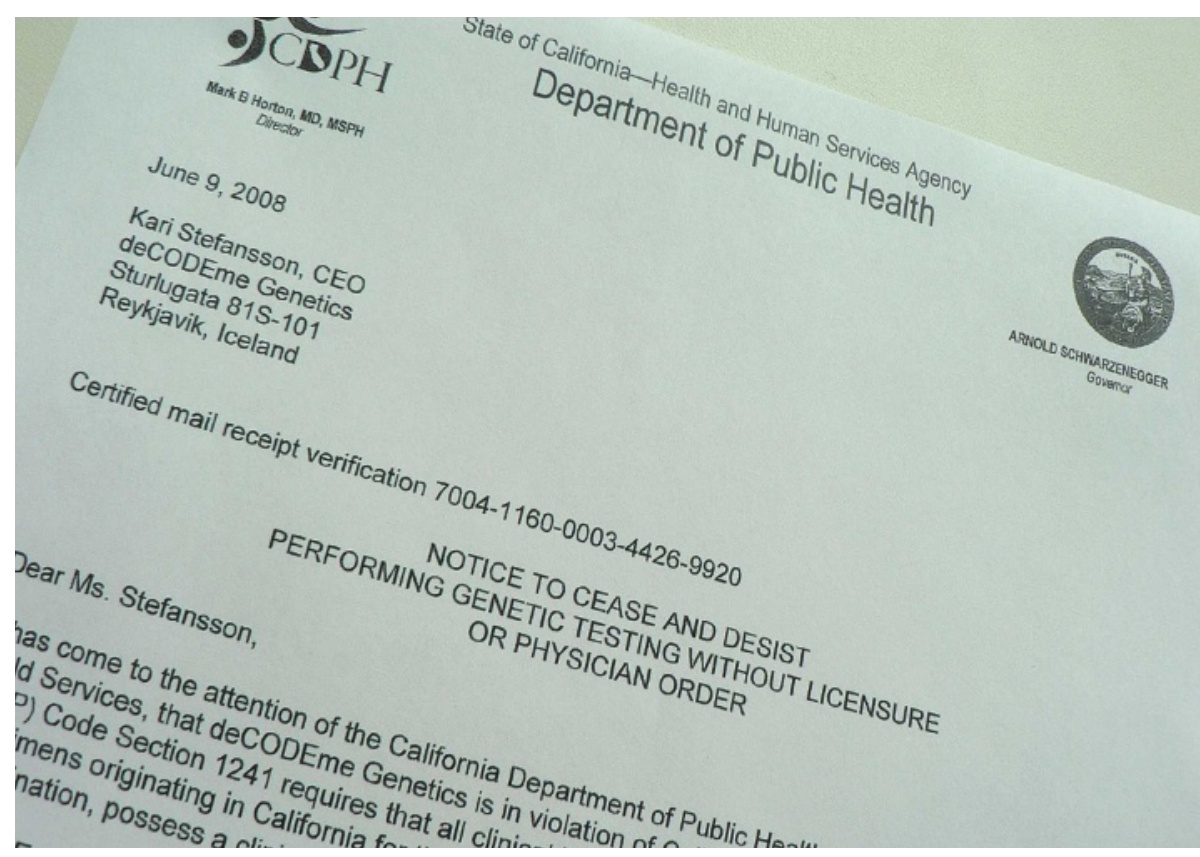

investigation into 25 companies, of which 13 were ultimately sent letters. Nickel told the meeting: "We [are] no longer tolerating directto-consumer genetic testing in California." Under California law, the companies could be fined up to US $\$ 3,000$ per day for each violation if there is no "immediate jeopardy" to state residents - and from $\$ 3,050$ to $\$ 10,000$ per day if there is.

23 andMe declined an interview request. It released a statement emphasizing that it is an "informational service", and

“It doesn't increase your risk. It measures your risk." said it is "eager to work with" regulators in California and elsewhere to develop appropriate regulations to govern the nascent industry.

But two of the companies dispute the charges in the letter. Mari Baker, chief executive of Navigenics, based in Redwood Shores, says that its tests are read by a licensed, certified laboratory and that a company physician is involved both in the approval of a genetic-test order and when the results are released to a customer. "It's important to do this the right way," says Baker. "And that we are doing. So this has come as quite a surprise. The only conclusion we can come to is we have not properly informed the state as to all the steps we have in place. We have reached out to them to try to schedule such a meeting."

Stefansson says that deCODE is not marketing to California residents; its website lists California among several states for which the company's deCODEme Genetic Scan "may omit certain information" because of state law.
He says that his company is in the process of trying to obtain a California licence, but that the state has been unresponsive. He is a physician and oversees the ordering process for deCODE, he says, adding that a large proportion of the test requests the company receives are from people's personal physicians.

Even so, he calls the legality of California's requirement that a physician order a genetic test "questionable". He says: "I don't think that they can basically tell the people of California that 'you cannot order a test like this for yourself without going to a physician'. I don't think they can raise that kind of barrier." He argues that a genetic test is not a medical intervention like, say, a prescription for a cholesterol-lowering drug. "It doesn't increase your risk. It doesn't decrease your risk. It measures your risk. It's a description of who you are."

The state Department of Public Health which is no longer making Nickel available for interviews - declined to say whether a company-employed physician who oversees orders initiated by customers through the Internet would meet its requirement that a physician order the genetic test.

That has been a grey area among regulators and policy-makers, says Kathy Hudson, director of the Genetics and Public Policy Center at Johns Hopkins University in Washington DC. "Is a doctor who is your personal physician, who has a fiduciary responsibility to you, 
the same as a company doctor? Is it really the same thing to call up a company who is trying to sell you a product and have their doctor, who receives a pay-cheque from them, advise you? To me, it is not the same thing."

The Californian law does not prevent statebased companies from marketing the tests to consumers residing outside the state. But a muddle of different state laws across the United States provides a confusing array of regulations on the issue.

New York's Department of Public Health has sent similar letters to 26 companies since last November. In response, 23 andme and Navigenics have submitted business plans that the department is reviewing, says its spokesman Jeffrey Hammond. "The good news for both 23 andme and Navigenics is the labs they are proposing they use for their lab work are known to the department and have a history of compliance with us." Hammond adds: "Our goal is not to levy fines. It is to bring companies who want to do business in New York into compliance with state law."

Hudson says that the California and New York letters point out the conspicuous lack of unifying federal regulation of genetic testing. The law "is very inconsistent from state to state at a time when the risks to consumers do not vary state to state - and when we have businesses that are certainly operating state to state".

Ryan Phelan, chief executive of DNA Direct, says that the one-size-fits-all approach of the letters is a cause for concern, because tests being offered range from those predicting serious diseases to "fun to know" information with no bearing on a person's health. "There is going to be increasingly a need for nuanced regulation. All genetic tests should not be considered the same."

\section{Biogen fights takeover bid}

The latest chapter in the battle over Biogen Idec, a prominent US biotechnology firm, ended last week when shareholders rejected billionaire investor Carl Icahn's bid to oust three members of the company's board of directors. The decision was a clear defeat for Icahn's plan to gain control of the company, which is based in Cambridge, Massachusetts, and a victory in Biogen's struggle to remain independent.

The fight between Icahn (pictured) and Biogen began last August, when Icahn announced that he had acquired $1 \%$ of the company's stock, making him one of its biggest investors. At first, Biogen officials weren't sure what to make of the news, says Naomi Aoki, Biogen's director of public affairs. Icahn is a classic corporate raider, known for gaining control of companies and then forcing them to take actions that increase the value of their stock. Over the past 30 years, Icahn has compelled many of his investments to sell their assets altogether.

"We knew his reputation," says Aoki. "But I don't think it was clear to us right from the beginning how everything would play out."

Icahn's goals fit cleanly with the drug industry's rising demand for biotechnology companies. In April 2007, pharmaceutical giant AstraZeneca surprised analysts by paying US $\$ 15$ billion for MedImmune, a Maryland-based biotechnology company. Icahn, a MedImmune shareholder, later acknowledged that he had pressured
MedImmune's board to sell, and had threatened a hostile takeover if the company did not comply. Biogen, a 30-year-old company with several candidate drugs in the pipeline, is worth $\$ 23$ billion.

In October, Biogen announced that it would accept offers from firms interested in buying the company. It called off the hunt for a purchaser in December, saying that no one had come forward. Icahn accused Biogen of interfering with the search, sued the company for access to records pertaining to the failed sales process, and announced that he was nominating three candidates to the board of directors. It would have been the first step in a two-part plan to gain control of the board that would have been completed next year when four more seats on the 12-member board became available for re-election.

In a memo to shareholders issued two weeks before the vote, Icahn accused Biogen of lying to them about its attempts to sell the company. Biogen issued a letter of its own, saying in bold-faced capital letters: "Do not be misled by Carl Icahn."

On 19 June, a preliminary tally of shareholder votes showed that Biogen had won this round. Icahn has not said what his next move will be, and was not available for comment. But he now controls $4 \%$ of the stock and has said that he has some of the top ten investors on his side, suggesting that Biogen's battles may not be over. Heidi Ledford

\section{Scientists get online news aggregator}

A Canadian graduate student dissatisfied with science coverage on online sites such as Google News and Yahoo News has created a news aggregator especially for scientists.

Michael Imbeault, an HIV researcher at the Université Laval in Quebec, launched his fully automated site called e! Science News (http://esciencenews.com) last month. It has already attracted 300,000 different users, and averages 5,000 visits a day, he says.

News aggregators display headlines and snippets from other media sources, but don't produce their own content. Of the top five online US news sites, three are aggregators - Google News, AOL News and Yahoo News - and only two - CNN.com and MSNBC.com - generate original content. Yahoo and AOL use human editors and source almost all science stories from wire agencies, such as Reuters. Google News uses computer algorithms to aggregate headlines from thousands of news sources, ranking them by how often and on which sites stories appear.
Science and technology coverage on Google News, for example, is notoriously devoid of basic science. Imbeault's site indexes science news sites, clusters similar articles together on the basis of the frequency of word co-occurrence, and then uses Bayesian statistics to automatically assign articles to topics such as astronomy, health and climate. It then ranks them using factors such as timeliness, and the number of sites reporting the same news, which indicates the story's importance. At present, it is limited to around 40 news sources - including Nature News, The New York Times science section and institutional news sites such as NASA, which offer free content for at least a period - but this will be increased, he says.

Imbeault built the site on top of the Drupal open-source content management software. He says that his aggregator will also be improved by moving to semantics-based techniques that better capture the meaning of a text.

Declan Butler 